\title{
Strategic Marketing Planning Practice in SMEs and A Case Study in Turkey
}

\author{
Yakup Durmaz ${ }^{1}$, Ali Açıkgöz² \\ ${ }^{1}$ Faculty of Economics Administrative and Social Sciences \\ Director of the Institute of Social Sciences \\ Hasan Kalyoncu University, Turkey \\ Email: yakup.durmaz [AT] hku.edu.tr \\ ${ }^{2}$ Hasan Kalyoncu University \\ Doctorate Student, Turkey
}

\begin{abstract}
This study aims to find whether strategic marketing planning is adequate in Small and Medium-sized Enterprises. Without efficient marketing, it is almost impossible for businesses to compete with others or to continue their businesses. This research studies the strategic marketing planning practices in SME sin the Diyarbakir province of Turkey. The study was conducted on businesses in an organized industry site of Diyarbakar. For data collection, semistructured interviews were made. The population of the research consists of people in charge of the SMEs. The results show that the SMEs on which the study was conducted were not on an adequate level when it comes to strategic marketing planning. According to the findings, the businesses in the study used dynamic pricing. The reason for this practice can be competition, exchange rates and the fluctuations in interest rates.
\end{abstract}

Keywords --- marketing, marketing management, strategic marketing planning

\section{INTRODUCTION}

Two major factors are affecting the economy today. One of them is technology, and the other one is globalization. Technology does not only affect people materially, but it also affects their mindsets. It also triggers the second effective power, globalization. The "global village" that McLuh an mentions is a reality now [11]. Businesses can survive by adapting thems elves to new developments and innovations [8]. New developments undoubtedly affect marketing, which is one of the most important functions of businesses. Marketing has been described differently by different authorities. Some of these definitions are as follows.

Marketing can be defined as all of the activities done by people to finalize or ease the change [10]. Marketing is one of the most critical components of the success of a business and has a significant effect on increasing the prosperity of a country [20]. E. Jerome McCarthy from the University of Michigan describes marketing as: "The level of performance of an organization to achieve its goals of managing the product and service flow from the producer to the customer in order to fores ee the needs of a customer or a buyer." John A. Howard from Columbia University described marketing as follows: "detecting the needs of the customers, conceptualizing these needs in line with the production capacity of the organization, transferring this conceptualization to the possible power laws of the organization, conceptualizing every production from that point on according to the needs of the customers and transferring this conceptualizing to the customer" [21]. Marketing management is designing, planning, conducting, and controlling the programs to make the changes expected fromthe target customer, either for mutual or individual gains [11]. Strategic marketing is a part of strategic management and one of the development stages of or marketing. It ensures the gathering and evaluation of information on market structure and competitors and that executives make decisions according to these evaluations [14]. The definitions show that strategies have two es sential characteristics; the first is that they are made before taking action, and the second is that they are developed consciously and purposefully [15].

Throughout the last decade, the marketing environment has changed dramatically and universally. The most important of these changes is the emergence of concepts like "new consumer" and "new competition" [6]. The fact that strategic marketing has come to the fore as a research field can be seen as the projection of the perspectives, paradigms, theories, concepts, frameworks, principles, methods, models and metrics of the last couple of decades [22]. 
Since the 70s, the planning function has raised the awareness that the strategic planning approach lacks certain aspects. One unknown factor was adapting to the market, this process caused a static character development, and the en vironment had increasingly become more dynamic.

The $21^{\text {st }}$-century concept of marketing has developed further than the concepts of the $20^{\text {th }}$ century and has become a "strategic concept" that regards everything in marketing, necessary. Not only the product and customer but also external factors like competition, technology, government policies, products of rival companies, prices, positioning and branding have also become important [9].

The essence of strategic management is an integrated organizational force that aims to ensure and maintain the competitive advantage of the individual unit of works (Day and Wensley, 1983). A typical strategic marketing plan is a combination of marketing goals, marketing strategies, marketing tactics, marketing budget and marketing action plans (Sirgy, 1996). However, implementing the determined strategies is not an easy task. In the past, many bu sinesses survived without a plan. The reas on for their survival was the abundance of resources and opportunities [12]. However, today it is pos sible for bu sinesses to be successful by knowing their weak and strong points, analyzing them, and deciding on proper procedures. Perception of opportunities and threats, using these opportunities and eliminating the threats are the initial steps for success. As Kotler said, marketing is the art of finding, developing and profiting from opportunities [11]. The literature on strategic marketing planning shows that businesses with marketing planning systems will be more successful than those who have not. In addition, the difference between theory and application shows that there are many obstacles to the application of marketing planning [13]. Certain steps of strategic marketing planning include analysis and research [3]. These processes are shown in Figure 1.

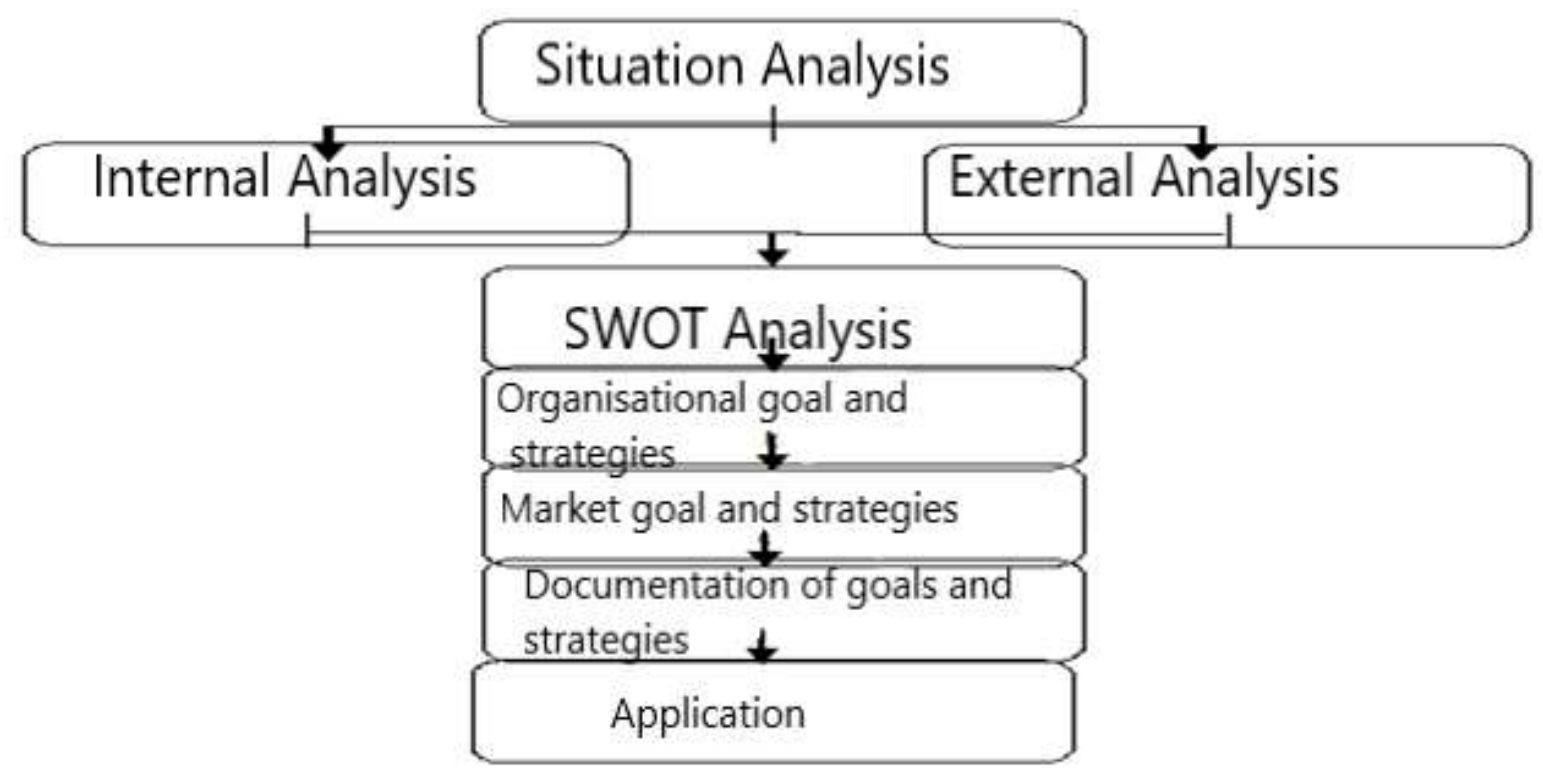

Figure 1. The role of marketing research in strategic marketing planning process Source:Tammo H. A.; Bijmolt, Ruud T. Frambach and Theo M. M. Verhallen, 1996: 83-98

Strategic analyses have an increasingly important role in strategic marketing. As Figure 1 suggests, internal and extemal analys is of strategic marketing planning is prioritized. SWOT analysis, where weak and strong threats are detected, is also important. After these steps, strategy and goals, market strategy and goals should be determined and documented. It is crucial for the plan that these steps are regularly followed.

Marketing planning is a process that uses a certain set of techniques to help the management in the application and help design the envisioned future. This process is a neutral one and the result being bad or good depends on the design and application ability of the management [18]. 


\section{METHODOLOGY}

A qualitative research method was used in this res earch to serve its primary purpose. The research was designed as a case study. A case study is the research of the factors related to one or several situations with a comprehensive approach and the analy sis of the interactions between these situations [7].

The first characteris tic of a case study is that it has limits, which means that the limits between the case and the context should be clearly defined. The second characteristic is determining the situation or the case. The third characteris tic is its comprehensive quality. The fourth characteristic is using data collection techniques like observation, interview and document analysis [7]. This research analyzes the strategic marketing planning applications of SMEs.

\subsection{Participant Group}

The participant group of this study consis ts of 8 SMEs in Diy arbakır Organized Industrial Site. The names of the SMEs in the study were kept hidden, in stead a code was used to represent each. The SMEs that participated in this study work in different sectors.

\subsection{Data Collection Tools}

Semi-structured interviews were made to collect data. In semi-structured interviews, the questions and topic titles that the researcher prepared beforehand guides the res earcher. Semi-structured interviews help the researcher to proceed with guidance and to interview in detail if neces sary. While a document analysis is the analysis of written, vis ual and audio material on the research topic [7].

The participants were asked 8 questions. The content of the questions is related to strategic marketing planning applications. As semi-structured interviews necessitate in-depth research, the participants were also asked questions besides the presetquestions.

\subsection{Data Analysis}

Qualitative data analysis is a heuristic process. The researcher organizes the collected data, synthesizes themto reveal the patterns and reports the findings. According to Dey, there are three steps in qualitative data analysis: description, classification and association [7].

Descriptive and content analyses were made on the collected data. Descriptive analysis is a qualitative data analysis method that includes the summarization and interpretation of the data collected through various data collection methods according to predetermined themes. Content analysis is a widely used method and is mostly used to analyze visual or written material. In content analysis, which follows a deductive logic, the researcher develops categories about his/her research topic [17]. Matrix was developed through conducting content and descriptive analysis of the collected data.

\section{FINDINGS}

The findings of the research conducted through semi-structured interviews havebeen summarized and analyzed in the table below.

Table 1. SMEs and Information of The Participants

\begin{tabular}{|l|l|l|l|l|l|}
\hline $\begin{array}{l}\text { KOBİ } \\
\text { Kodu }\end{array}$ & Sector & $\begin{array}{l}\text { Established } \\
\text { in }\end{array}$ & Occupation & Education & Years of experience in SE \\
\hline SME1 & Chemistry & 2006 & GM & High School & 3 \\
\hline SME2 & $\begin{array}{l}\text { Ready-made } \\
\text { clothing }\end{array}$ & 2015 & GM & Associate Degree & 3 \\
\hline SME3 & Packaging & 2015 & SM & Bachelor's Degree & 3 \\
\hline SME4 & Aluminum & 2014 & ME & Bachelor's Degree & 4 \\
\hline SME5 & Food & 2003 & M & Associate Degree & 5 \\
\hline SME6 & Mining & 1998 & ME & Bachelor's Degree & 3 \\
\hline SME7 & Packaging & 2003 & GM & Bachelor's Degree & 15 \\
\hline SME8 & Textile & 1997 & BM & Associate Degree & 8 \\
\hline
\end{tabular}

SM: Sales Manager, M:Manager, GM: General Manager, BM: Board Member, ME: Marketing Executive 
The interview groups from the SMEs include 4 people with a bachelor's degree, 3 with an as sociate degree and 1 with a high school diploma. The research was carried on SMEs that work in chemistry, packaging, food, aluminum, mining, textile and ready-made clothing.

Table 2. Strategic Marketing Planning Process

\begin{tabular}{|l|l|l|l|l|l|l|}
\hline $\begin{array}{l}\text { SME } \\
\text { Code }\end{array}$ & $\begin{array}{l}\text { Situation } \\
\text { Analysis }\end{array}$ & $\begin{array}{l}\text { Environmental } \\
\text { Analysis (external- } \\
\text { internal) }\end{array}$ & $\begin{array}{l}\text { SWOT } \\
\text { Analysis }\end{array}$ & Goal Setting & $\begin{array}{l}\text { Budg } \\
\text { et }\end{array}$ & Documentation \\
\hline SME1 & - & - & - & + & - & - \\
\hline SME2 & - & - & - & + & - & - \\
\hline SME3 & + & + & + & + & - & - \\
\hline SME4 & - & - & - & - & - & - \\
\hline SME5 & - & - & - & + & - & - \\
\hline SME6 & + & + & - & + & - & - \\
\hline SME7 & - & + & - & + & - & - \\
\hline SME8 & + & + & - & + & - & - \\
\hline
\end{tabular}

+: Made, -: Not made

The research findings show that only 3 SMEs make situation analysis, the first and the most critical step of strategic marketing planning. The interviews of the participants show that external and internal environmental analysis is made by 4 SMEs, goal setting by 7 SMEs and SWOT analysis by only 1 SME.

It has also been found that none of the SMEs have a budget saved for marketing planning. It has also been determined that SMEs do not write down their plans; they are only spoken.

Table 3. Market Classification

\begin{tabular}{|l|l|l|l|l|l|l|}
\hline $\begin{array}{l}\text { SME } \\
\text { Code }\end{array}$ & $\begin{array}{l}\text { Demogr. } \\
\text { \&Geograph. }\end{array}$ & $\begin{array}{l}\text { Income } \\
\text { Lvl. }\end{array}$ & $\begin{array}{l}\text { Psych. } \\
\text { Variable }\end{array}$ & $\begin{array}{l}\text { Consumer } \\
\text { Behavior }\end{array}$ & Expected Benefit & Others \\
\hline SME1 & + & - & - & + & + & \\
\hline SME2 & + & - & - & - & - & Seasonal \\
\hline SME3 & + & - & - & - & - & Indus trialized Areas \\
\hline SME4 & + & - & - & + & - & \\
\hline SME5 & + & + & - & - & + & \\
\hline SME6 & - & - & - & + & + & \\
\hline SME7 & + & - & - & - & + & SectoralClas sification \\
\hline SME8 & + & - & - & + & + & \\
\hline
\end{tabular}

$+:$ Made, $-:$ Not made

Market clas sification as a term was first used by W. Smith (1956). As an alternative to the increasing competition of mas s marketing, Smith suggested a market classification approach and stated that if products are put on a suitable market, it will succeed. American Marketing Association (AMA 2008) defined market classification as "classifying the market into different sub-categories that meet similar needs and act similarly." AMA stated that market classes should be measurable, accessible, can bedifferentiated fromothers, consistent and large enough [16].

Classifying a vast market into businesses, countries or customers that partially need the same products or services is called market clas sification. Market classification is a 3-step process: research, analysis and evaluation. Firs tly, the data related to the market is collected. After analyzing the data, the market is clas sified, and the target market is determined [1].

It has been found that almost all of the SMEs that participated in the research (7 SMEs) make a geographical clas sification. 5 SMEs make benefit clas sification. 4 of the SMEs that make geographical positioning als o make expected benefit classification. 4 SMEs make classification while also considering customer behavior. Aside from the preset variables, there were other answers classifications like indus trialized areas and sectoral. 
Table 4. Target Market Classification

\begin{tabular}{|l|l|l|l|l|l|}
\hline SME Code & Mass Market & $\begin{array}{l}\text { Niche } \\
\text { Markets }\end{array}$ & Local Market & Pers onalized & Others \\
\hline SME1 & - & - & + & - & Construction Sector \\
\hline SME2 & + & - & - & - & \\
\hline SME3 & - & + & - & - & Target market in $250 \mathrm{~km}^{2}$ radius \\
\hline SME4 & - & + & - & - & \\
\hline SME5 & + & - & - & - & Focused on foreign market \\
\hline SME6 & - & - & + & - & \\
\hline SME7 & - & + & + & - & Manufacturing businesses \\
\hline SME8 & + & - & - & - & \\
\hline
\end{tabular}

+ : Made, - :Not made

When it comes to target market clas sification, it has been found that 3 SMEs have a mas s target market, 2 SMEs have niche target markets, $1 \mathrm{SME}$ has both niche and a local target market. Also, there was an SMEthat specifically targets the cons truction sector and another SME that targets manufacturing businesses in a $250 \mathrm{~km}^{2}$ radius. Another SMEstated that it targets businesses that manufacturers for the local market.

Table 5. Price Positioning

\begin{tabular}{|l|l|l|l|l|l|}
\hline $\begin{array}{l}\text { SME } \\
\text { Code }\end{array}$ & $\begin{array}{l}\text { Low price, high } \\
\text { number }\end{array}$ & $\begin{array}{l}\text { Acc. To } \\
\text { income }\end{array}$ & Dynamic Pricing & $\begin{array}{l}\text { Acc. To the } \\
\text { Equivalent } \\
\text { Product }\end{array}$ & $\begin{array}{l}\text { Acc. To the Added } \\
\text { Value of the Product }\end{array}$ \\
\hline SME1 & + & - & + & + & - \\
\hline SME2 & + & + & + & + & - \\
\hline SME3 & - & - & + & & - \\
\hline SME4 & - & + & + & - & - \\
\hline SME5 & - & & + & - & - \\
\hline SME6 & - & - & + & - & - \\
\hline SME7 & & & + & & + \\
\hline SME8 & - & - & + & - & - \\
\hline
\end{tabular}

+ : Made, - :Not made

The most striking thing about the pricing is that all of the SMEs implement dynamic pricing. They stated that increased competition, exchange rates and fluctuations in the interest rates are the main reasons for implementing dynamic pricing. In addition to dy namic pricing, other pricing methods are als o implemented. 1 SME implements pricing according to the added value of the product.

Table 6. Budget for Branding

\begin{tabular}{|l|l|l|l|l|l|}
\hline SME Code & No Budget & \% 1 (Ciro) & \% 3 (Ciro) & \% 5 (Ciro) & \% 10(Ciro) \\
\hline SME1 & + & - & - & - & - \\
\hline SME2 & - & + & - & - & - \\
\hline SME3 & + & - & - & - & - \\
\hline SME4 & + & - & - & - & - \\
\hline SME5 & & + & - & - & - \\
\hline SME6 & - & + & - & - & - \\
\hline SME7 & - & + & - & - & - \\
\hline SME8 & - & + & - & - & - \\
\hline
\end{tabular}

+ : Made, - :Not made

Branding is vital for businesses. A brand is at the center of marketing activities, it has the power to affect customer behavior, and it helps differentiate between services and products. A brand is a combination of logos, figures or names that determines theidentity of a service and that makes it different fromits competitions [2]. 
5 of the SMEs stated that they save $1 \%$ of the revenue for branding. While 3 SMEs stated that they have no budget for branding.

Table 7. Marketing Mix

\begin{tabular}{|l|l|l|l|l|l|}
\hline KOBİ Kodu & Product & Place & Price & Promotion & Other \\
\hline SME1 & + & + & + & + & People \\
\hline SME2 & + & + & + & + & People, Physical Opportunities \\
\hline SME3 & + & + & + & + & People \\
\hline SME4 & + & + & + & + & People \\
\hline SME5 & + & + & + & + & People \\
\hline SME6 & + & + & + & + & People, Physical Opportunities \\
\hline SME7 & + & + & + & + & \\
\hline SME8 & + & + & + & + & People, Physical Opportunities \\
\hline
\end{tabular}

$+:$ Made, - :Not made

To gain an active res ponse, in marketing management, it is essential to org anize and the product, price, place, promotion (4p) elements and make themsuitable for the business structure [10].

It has been found that even though SMEs make basic level plans, they include marketing mix elements. The people factor and physical opportunities are also found to be important.

Table 8. Dis tribution Channels

\begin{tabular}{|l|l|l|l|l|l|}
\hline SME Code & Distributor & Franchise & Store & E-commerce & Others \\
\hline SME1 & - & + & - & - & Beginner \\
\hline SME2 & - & + & - & - & \\
\hline SME3 & - & - & - & - & One-to-one Marketing \\
\hline SME4 & - & - & - & - & One-to-one Marketing \\
\hline SME5 & + & - & - & - & \\
\hline SME6 & - & - & - & - & Direct Sale \\
\hline SME7 & - & - & - & - & One-to-one Marketing \\
\hline SME8 & - & + & - & + & One-to-one Marketing \\
\hline
\end{tabular}

+ : Made, - :Not made

Thinking that the term "distribution" only stands for transferring the products and services to the consumer can cause some misunderstandings. A distribution channel can be defined as a structure that is created by intervening or first-hand parties like internal units, external agencies, wholesalers, retailers, franchis ees and dis tributors to help market the services to the consumers [5].

The findings show that most of the SMEs use the one-to-one sale method. 3 SMEs use franchising channels, 1 SME uses distributor channels, and 1 SMEuses an e-commerce channel.

Table 9. Cus tomer Experience

\begin{tabular}{|l|l|l|l|l|l|}
\hline $\begin{array}{l}\text { SME } \\
\text { Code }\end{array}$ & $\begin{array}{l}\text { Promotion\& } \\
\text { Information }\end{array}$ & $\begin{array}{l}\text { Tailor-made } \\
\text { Products }\end{array}$ & CustomizedServices & $\begin{array}{l}\text { Peer-to-peer } \\
\text { Communication }\end{array}$ & \begin{tabular}{l} 
Others \\
\hline SME1
\end{tabular}$-$ \\
\hline SME2 & + & - & - & + & \\
\hline SME3 & + & - & - & + & \\
\hline SME4 & - & - & - & + & \\
\hline SME5 & + & - & - & + & \\
\hline SME6 & + & - & - & + & \\
\hline SME7 & - & - & - & + & \\
\hline SME8 & + & - & - & + & \\
\hline
\end{tabular}

+ : Made, - :Not made 
By investigating customer experience, it is aimed to evaluate how SMEs maintain their relationships with the customer and what kind of methods they u se to manage customer relationships. It has been found that peer-to-peer communication is used as an efficient method. In addition, 5 SMEs stated that they also use promotional activities and share these with the customers and occasionally inform the cus tomers through email.

\section{CONCLUSION}

It is an undeniable truth that marketing has gained importance in a highly competitive environment. Therefore, businesses need to create high disciplined marketing plans. Analy sis of the market, competitors, competition conditions and the comparis on and analysis of the capability of products and services are among the most important steps to take. The SMEs on which this study was carried out make strategic marketing plans on a significantly basic level. This can have different reasons, and they can be the topic of future research. Another finding of this study is that investment in branding is significantly low.

According to the 2017 data of TUIK, the population ofDiyarbakir is 1.699 .901 ; this makes it the $12^{\text {th }}$ most populated city in Turkey. It has a young population. Diyarbakır is a 6 . encouraged investment zone ${ }^{1}$, and because it is close to Iran, Iraq, and Syria, it is close to the middle east market. Despite the advantages the city has, the fact that it has no product or services representing Turkey can be another research topic.

\section{REFERENCES}

[1] Akoğul, S., and E. Tuna. (2017). "Kümeleme Ve Çok Boyutlu Ölçekleme Analizleri İle Endüstriyel Pazar Bölümlendirmesi Ve Etkili Ürünlerin Belirlenmesi”, Çukurova Üniversitesi Sosyal Bilimler Enstitüsü Dergisi 25(1): $29-42$.

[2] Alan, H., and O. Yeloğlu. (2013). “Markalaşma ve Yenilikçilik” , İktisadi Yenilik Dergisi 1(1): 13-25.

[3] Bijmolt, T.H. A., and R.T. Frambach.(1996). "Strategic Marketing Research”, Journal of Marketing Managemen 12: 83-98.

[4] Day, George S, and Robin Wensley. (1983). "Marketing Theory with Strategic”, Journal of Marketing 47(4): 79-89.

[5] Eroğlu,H., H. Kanıbir, and N. Eker. (2008). "Endüstriyel İşletmelerin DağıtımKanalı Seçimini Etkileyen Faktörlerin Belirlenmes ine Yönelik Bir Çalışma”, Süleyman Demirel Üniversitesi İktisadi ve İdari Bilimler Fakültesi Dergisi 13(1): $95-110$.

[6] Gilligan, C., and R. M.S. Wilson. (2009). “Strategic Marketing Planning”, London and New York: Routledge.

[7] Gürbüz, Sait, and Faruk Şahin. (2017). “Sosyal Bilimlerde Araşttrma Yöntemleri”, Ankara: Seçkin.

[8] Kaygusuz, Sait, and Şükrü Dokur. (2009). “İşletmelerde Stratejik Planlama ve Bütçeleme”, Bursa: Dora.

[9] Keegan, Warren J. (2004). "Strategic Marketing Planning: A Twenty-First Century Perspective”, International Marketing Review 21(1): 13-16.

[10] Kotler, P. (1975). “Pazarlama Yönetimi”, Ankara: Ayylldı Matbaası.

[11] Kotler, P. (2003). "Kotlerve Pazarlama”, İstanbul: Sistem Yayınc1lk.

[12] Lackman, C. (2013). "Competitive Intelligence and Forecasting Systems : Strategic Marketing Planning Tool for SME ' s", Atlantic Marketing Journal 2(2): 98-111.

[13] Mcdonald, M. (1996). "Strategic Marketing Planning: Theory, Practice and Research Agendas Marketıng", Joumal of Marketing Management (12): 5-27.

[14] Milichovsky, F., and I. Simberova. (2015). "Marketing Effectiveness : Metrics for Effective Strategic Marketing",

${ }^{1}$ Turkey has 6 encouraged investment zones. Cities in $1^{\text {st }}$ encouraged investment zone are relatively developed cities while cities in $6^{\text {th }}$ encouraged investment zone a re cities in which the government encourages people to invest the most. 
Inzinerine Ekonomika-Engineering Economics 26(2): 211-19.

[15] Mintzberg, H. (2001). “The Strategy Concept I: Five Ps For Strategy”, California Management Review: 11-24.

[16] Nacar, R., and U. Nimet. (2014). “Küresel Tüketici Kültürü Kavramıla Birlikte Değişen Pazar Bölümlendirme Yaklaşı ımları: Ulus lararası Pazarlama Literatürüne Bakış” Yalova Sosyal Bilimler Dergisi (8).

[17] Özdemir, M. (2010). "Nitel Veri Analizi: Sosyal Bilimlerde Yöntembilim Sorunsalı Üzerine Bir Çalışma", Eskişehir Osmangazi Üniversitesi Sosyal Bilimler Dergisi 11(1): 323-43.

[18] Pulendran, S., and R. Speed. (1996). "Planning and Doing: The Relationship between Marketing Planning Styles and Market Orientation”, Journal of Marketing Management 12(1-3): 53-68.

[19] Sirgy, M. J. (1996). “Strategic Marketing Planning Guided by theQuality-of-Life (QOL) Concept”, ournal of Business Ethics 15:241-59.

[20] Tokol, T. (1998). “Pazarlama Yönetimi. Bursa”, Vipaş.

[21] Trout, J., and A Ries. (2003). “Pazarlama Savaşı”, İstanbul: Optimist.

[22] Varadarajan, R. (2010). "Strategic Marketing and Marketing Strategy: Domain, Definition, Fundamental Is sues and Foundational Premis es", Journal of the Academy of Marketing Science 38(2): 119-40. 